Technical Paper

\title{
Development of Quality Control Indexes of Feedstock for Cellulosic Bioethanol Production
}

\author{
Aiko AkiYama *1, Tsuyoshi SuZUki ${ }^{* 2}$, Masahiro NiwA *3, Yasutoshi IGUCHI *3, \\ Akira FUKUDA *3, and Shuichi MiHASHI *1
}

(Received May 28, 2014)

\begin{abstract}
セルロース系バイオエタノール原料作物の品質管理指標の開発
秋山愛子*1 ${ }^{2}$ 鈴木 剛*2, 丹羽雅裕*3, 井口靖敏*3, 福田 明*3, 三橋秀一 $* 1$
\end{abstract}

For producing cellulosic bioethanol stably, quality control indexes of feedstock are required. From the fact that Napiergrass can be harvested throughout the year in tropical region, growth was used as quality control indexes of feedstock. Each Napiergrass which grew 3-7 months at same field was carried out ammonia pretreatment and enzymatic saccharification under the same condition. Enzymatic saccharification efficiency decreased as Napiergrass grew. However, when Napiergrass samples which grew 5 months under various different conditions were compared, enzymatic saccharification efficiency and content of components were obviously different. Therefore, growth was not suitable for quality control indexes. Correlation coefficient between enzymatic saccharification efficiency and each component in Napiergrass was investigated. There was moderately strong correlation between enzymatic saccharification efficiency and lignin content (thioglycolic acid method, TGAL). From the above, TGAL was suitable for quality control indexes of feedstock for cellulosic bioethanol production. Furthermore, multiple linear regression analysis using saccharification efficiency as objective variable and contents of each component as explanatory variables, revealed that saccharification efficiency can be predicted from the contents of TGAL, glucose and crude protein with standard error of 3.50.

セルロース系バイオエタノールを安定に製造するためには, 原料植物の品質管理指標が必要である。熱帯では, ネピアグ ラスを通年で栽培できるため，栽培期間を指標に用いることにした。同じ戋場で $3 ， 4 ， 5 ， 6$ および 7 ケ間栽培したネピア グラスを，それぞれ同じ条件でアンモニア処理を施し酵素糖化を行ったところ，栽培期間が長くなると糖化率は減少した。 しかし，栽培条件が異なると，ネピアグラスは同じ栽培期間でも糖化率や成分組成にばらつきが見られたため，栽培期間の みを原料の管理指標とするのは適切ではないと考えられた。そこで, 原料の成分組成と糖化率の単相関係数を調べた結果, 原料のリグニン (チオグリコール酸法)（以下，TGAL と略記）と糖化率にやや強い相関が見られたことから，原料管理の 指標にはTGALが適していると考えられた。さらに, 糖化率を目的変数, 各成分を説明変数として重回帰分析を行ったところ, TGAL，グルコース，粗タンパク質から，標準誤差 3.50 で糖化率を予測できることがわかった。

Key Words

Cellulosic bioethanol, Energy crop, Napiergrass, Ammonia treatment, Saccharification, Lignin

\footnotetext{
$※ 1$ The Research Association of Innovative Bioethanol Technology

2-6-3, Otemachi. Chiyoda-ku, Tokyo 100-8162, Japan

※2 TOYOTA MOTOR CORPORATION

4-7-1, Meieki, Nakamura-ku, Nagoya-shi, Aichi 450-8711, Japan

※3 JX Nippon Oil \& Energy Corporation

8. Chidori-cho, Naka-ku, Yokohama-shi, Kanagawa 231-0815, Japan
}

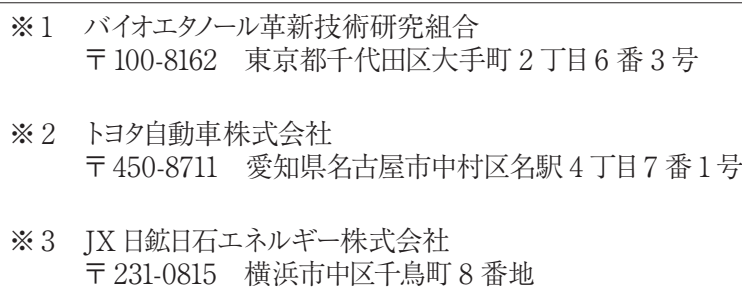

※1 バイオエタノール革新技術研究組合 干 100-8162 東京都千代田区大手町 2 丁目 6 番 3 号

※2 卜ヨ夕自動車株式会社 † 450-8711 愛知県名古屋市中村区名駅 4 丁目 7 番 1 号

※3 JX日鉱日石エネルギー株式会社 于 231-0815 横浜市中区千鳥町 8 番地 


\section{1. 緒 言}

セルロース系バイオエタノールの原料としてネピアグラスは 非常に有望な特性を持っている。バイオマスの生産性が高 く, インドネシアなどの熱帯で年間の乾物収量が $50 \mathrm{t} / \mathrm{ha}$ 得 られるだけでなく，年間を通して栽培・収穫できるため，周 年供給が可能である。この特性は, 植物を原料にしてエタノー ルを年間を通じて生産する上で欠かせない重要なポイントで ある。また，バイオエタノールの原料に用いる植物を栽培す る際には，食料生産と競合しないことが求められるが，ネピ アグラスは環境ストレス耐性が高く, 食用作物の栽培に適さ ない瘦せた土壤でも収量低下が少ないため 1 ， エネルギー資 源作物として大いに期待できる。

さらに, 酵素糖化や発酵といったエタノール製造工程にお いては, 高いエタノール収率を得るために, 糖含量が多く, かつ, 酵素による糖への変換効率が良い原料が求められて いるが，ネピアグラスの茎部には栽培期間 2 ケ月程度でもセ ルロースが $40 \%$ 近く含まれており 2)，製造工程の観点からも 原料として有望である。

しかし，一般に，ネピアグラスは 2 ケ月周期で収穫し飼料 利用されるため, エネルギー資源作物として最大収量得るた めに長期間栽培した場合の成分組成の知見が少ない。また, 著者らは，大規模で安定供給が可能なエタノールの一貫製 造技術の開発に取り組んで扔り，年間 20 万 $\mathrm{kL}$ 規模のエ夕 ノール生産を目指している本プロジェクトでは，一日当たり約 $2000 \mathrm{t}$ の原料を必要とするため, 各地の圃場から収穫してく ることになる。このため, 原料の品質管理が非常に重要となっ てくるが，上記の理由からどのような指標を用いれば原料管 理を適切に行えるのか定かでない。また，本プロジェクトで は, 酵素糖化の前処理工程にアンモニア処理を採用してい る。アンモニア処理の利点は, 原料に含まれる多糖や単糖 など糖類の水への流出や過分解といった損失が無いことで, 原料の糖含量うアンモニア処理後の糖含量である。つまり, 原料の糖含量の多頞が後段のエタノール製造工程に影響を 与えるため, 原料の品質管理が重要となってくる。そこで本 研究では，長期間の栽培によるネピアグラスの成分組成の変 化や，栽培期間や成分組成の変化が酵素糖化に与える影響 を明らかにするとともに，バイオエタノール原料としての品質 管理に適した指標を得ることを目的とした。

\section{1 試 料}

\section{2. 実 験}

インドネシア国ランプン州で栽培条件を変え $3,4,5,6$ および 7 ケ月間栽培したネピアグラス (Pennisetum purpureum Schumach.) の試料 34 種類を供試した。栽培地は，条件が 異なる 8 戋場を選択し, ネピアグラスの茎苗を株間 $50 \mathrm{~cm}$, 畦間 $1 \mathrm{~m}$ で植え付けた。土壤の肥沃度を、コーン等の食用 作物の栽培に適した土地をGood，キャッサバ等の原料作物 を栽培する土地を Normal, 生産性が低下し食料生産が成り 立たなくなった土地をキャッサバの収量 $5 \mathrm{t} / \mathrm{ha} /$ year 以下を 目安にPoor と定義した。施肥は, 化成肥料と堆肥のいず
れかを用いた。収穫は、ネピアグラスを地際で刈り, 地上部 全体（Whole），または，梢頭部を切除した茎下部（Bottom） の 2 種類に調製した。栽培時季は雨季, 半乾季, 乾季に分 類した。栽培条件を Table 1 に示す。

\section{2 アンモニア処理}

低圧二段アンモニア法 ${ }^{3)}$ で処理した。所定温度・所定量 のアンモニア存在下で, 原料バイオマス中のヘミセルロース ーリグニン間のエステル結合をアミド化開裂させて, エステル 開裂処理品を得た。常温で所定量の液体アンモニア存在下 で，前記エステル開裂処理品中のセルロースを嵩高い而型へ 変態させ, 低圧二段アンモニア処理品を得た。

\subsection{1 エステルのアミド化開裂処理}

Fig. 1 に示すような装置を用い, 実容量 5.35 L の反応器 (5 L) を用いて化学処理した。試料 $100 \mathrm{~g}$ を反応器 (5 L) に入れ，上部フランジを閉じ，系内を窒素で置換した。大 気圧になるまで窒素を排気後, $\mathrm{CaCl}_{2}$ 水溶液 - ドライアイスを 用いて反応器内温が $-10^{\circ} \mathrm{C}$ 以下になるまで冷却し，アンモニ アボンべの蒸気圧との差圧を利用して, 反応器内へアンモ ニアガスを移送した。バッチカウンター付きのマスフローメー ターを用いてアンモニアガスを反応器に 52.7 NL（40 g) 供 給した。直ちに, 反応器内温の制御温度を $120^{\circ} \mathrm{C}$ に設定し, 最高温度を $155^{\circ} \mathrm{C}$ に設定した鋳込みヒーターを用いて昇温し た。反応器内温が $115^{\circ} \mathrm{C}$ に達した時を処理開始とし, 2.5 時 間処理した。2.5 時間の平均温度, 圧力を処理温度圧力と した。処理終了後直ちに脱圧し，窒素によってアンモニアを 除去し, エステル開裂処理品を得た。

\subsection{2 セルロース結晶の皿型化処理}

Fig. 1 に示すような装置を用い, 反応器 $(0.25$ L) を用い て物理処理した。エステル開裂処理品 $40 \mathrm{~g}$ を反応器( $0.25 \mathrm{~L}$ ) に入れ，上部フランジを閉じ，処理に先立ち，系内を窒素 で置換し，さらに，アンモニアガスで置換した。 $\mathrm{CaCl}_{2}$ 水溶 液 - ドライアイス用いて反応器内温が $-30^{\circ} \mathrm{C}$ 以下になるまで冷 却し，アンモニアボンベの蒸気圧との差圧を利用して，反応 器内へアンモニアガスを移送した。バッチカウンター付きのマ スフローメーターを用いてアンモニアガスを反応器に $44.8 \mathrm{NL}$ （34 g) 供給した。アンモニア供給後直ちに冷却バスを外し, 室温雲囲気下にて 1 時間結晶膨潤化処理をした。そのとき の平均温度, 圧力は $-8.5^{\circ} \mathrm{C}, 0.3 \mathrm{MPa}$ であった。処理終了 後直ちに脱圧し, 最高温度を $50^{\circ} \mathrm{C}$ に設定した鋳込みヒーター を用いて加温しながら, 反応槽内温を $40^{\circ} \mathrm{C}$ 以下 (エステル開 裂反応が進行しないことを確認している温度）に制御した状 態で，窒素によってアンモニアを除去し，低圧二段アンモニ ア処理品を得た。

\section{3 成分分析}

Table 1 のネピアグラスについて，成分分析を行った。 灰分率, アルコール・ベンゼン可溶分, クラーソンリグニン, ホロセルロース， $\alpha$ - セルロース，へミセルロースは，いずれも 木材の化学成分分析法 ${ }^{4}$ によって行った。なお, ヘミセルロー 
Table 1 Cultivation condition of Napiergrass samples

\begin{tabular}{|c|c|c|c|c|c|c|}
\hline No. & Location & Land Type & Fertilizer & Growth & Part & Season \\
\hline 1 & \multirow{5}{*}{$\mathrm{K} 1$} & \multirow{5}{*}{ Normal } & \multirow{5}{*}{ Chemical } & 3 months & Bottom & Semi Dry \\
\hline 2 & & & & 4 months & Bottom & Semi Dry \\
\hline 3 & & & & 5 months & Bottom & Semi Dry \\
\hline 4 & & & & 6 months & Bottom & Semi Dry \\
\hline 5 & & & & 7 months & Bottom & Semi Dry \\
\hline 6 & \multirow{5}{*}{$\mathrm{K} 2$} & \multirow{5}{*}{ Normal } & \multirow{5}{*}{ Chemical } & 3 months & Whole & Semi Dry \\
\hline 7 & & & & 4 months & Whole & Semi Dry \\
\hline 8 & & & & 5 months & Whole & Semi Dry \\
\hline 9 & & & & 6 months & Whole & Semi Dry \\
\hline 10 & & & & 7 months & Whole & Semi Dry \\
\hline 11 & \multirow{9}{*}{ K3 } & \multirow{9}{*}{ Normal } & \multirow{9}{*}{ Chemical } & 3 months & Bottom & Dry \\
\hline 12 & & & & 4 months & Bottom & Dry \\
\hline 13 & & & & 5 months & Bottom & Rains \\
\hline 14 & & & & 5 months & Bottom & Rains \\
\hline 15 & & & & 5 months & Bottom & Rains \\
\hline 16 & & & & 5 months & Bottom & Dry \\
\hline 17 & & & & 5 months & Bottom & Dry \\
\hline 18 & & & & 5 months & Bottom & Rains \\
\hline 19 & & & & 5 months & Bottom & Rains \\
\hline 20 & \multirow{4}{*}{$\mathrm{KA}$} & \multirow{4}{*}{ Poor } & \multirow{4}{*}{ Chemical } & 5 months & Bottom & Semi Dry \\
\hline 21 & & & & 5 months & Whole & Semi Dry \\
\hline 22 & & & & 5 months & Bottom & Dry \\
\hline 23 & & & & 5 months & Bottom & Dry \\
\hline 24 & \multirow{6}{*}{$\mathrm{S}$} & \multirow{6}{*}{ Good } & \multirow{3}{*}{ Compost } & 5 months & Bottom & Semi Dry \\
\hline 25 & & & & 5 months & Whole & Semi Dry \\
\hline 26 & & & & 5 months & Bottom & Dry \\
\hline 27 & & & \multirow{3}{*}{ Chemical } & 5 months & Bottom & Dry \\
\hline 28 & & & & 6 months & Bottom & Rains \\
\hline 29 & & & & 6 months & Bottom & Rains \\
\hline 30 & \multirow{2}{*}{$\mathrm{L}$} & \multirow{2}{*}{ Poor } & \multirow{2}{*}{ Chemical } & 5 months & Bottom & Dry \\
\hline 31 & & & & 5 months & Bottom & Dry \\
\hline 32 & \multirow{2}{*}{ W } & \multirow{2}{*}{ Normal } & \multirow{2}{*}{ Chemical } & 5 months & Bottom & Rains \\
\hline 33 & & & & 5 months & Bottom & Rains \\
\hline 34 & $\mathrm{M}$ & Normal & Chemical & 5 months & Bottom & Rains \\
\hline
\end{tabular}

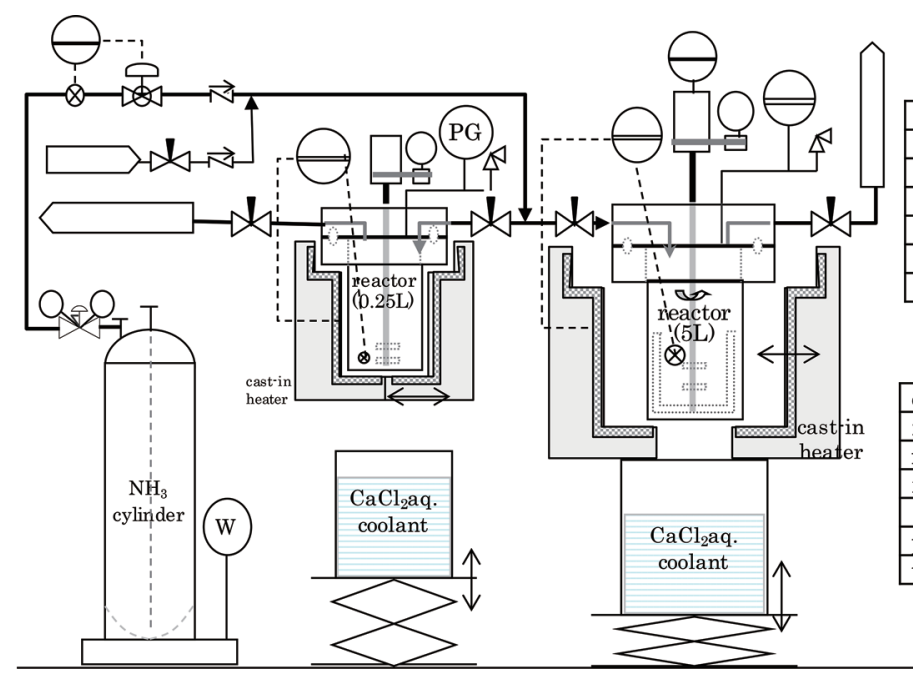

\begin{tabular}{|l|c|c|}
\hline equipment name & \multicolumn{2}{|c|}{ reactor(5L) } \\
\hline maker & \multicolumn{2}{|c|}{ Nitto Koatsu co. Ltd. } \\
\hline internal volume[L] & \multicolumn{2}{|c|}{5.35} \\
\hline material & \multicolumn{2}{|c|}{ SUS316 } \\
\hline & working & design \\
\hline pressure[MPa] & 18 & 20 \\
\hline temperature $\left[{ }^{\circ} \mathrm{C}\right]$ & 225 & 250 \\
\hline
\end{tabular}

Fig. 1 Ammonia pretreatment equipment 
スは, (ホロセルロース ) - ( $\alpha$ - セルロース) より求めた。

リグニン（チオグリコール酸法）（TGAL）は, Suzuki ら 5) の方法を用いて定量した。

粗タンパク質 $(\mathrm{CP})$, 結合タンパク $(\mathrm{BP})$, 中性デター ジェント不溶性タンパク（NCDIP），中性デタージェント繊維 $(\mathrm{NDF})$, 酸性デタージェント繊維 $(\mathrm{ADF})$, 酸性デタージェン トリグニン ( $\mathrm{ADL})$, 非繊維性炭水化物 (NFC), 粗脂質 ( $\mathrm{EE})$, 粗灰分, $\mathrm{Ca}, \mathrm{P}, \mathrm{Mg}, \mathrm{K}$, 当量比 $\mathrm{K} /(\mathrm{Ca}+\mathrm{Mg})$, 細胞内容 物 (OCC), 総繊維 $(\mathrm{OCW})$, 高消化性繊維 $(\mathrm{Oa})$, 低消化 性繊維 (Ob) は，飼料分析法 6) 7) に従って分析した。

アセチル基は，NREL 法 ${ }^{8}$ に従い酢酸を遊離させ，イオン クロマトグラフィーを用いて定量した。

また, Table 1 の原料ネピアグラスだけでなくアンモニア処 理後のネピアグラスについても，構成糖分析 ${ }^{8)}$ を行い，硫酸 加水分解により生成するグルコース量 (Glc) 拉よびキシロー ス量（Xyl）を定量した。

上記成分分析で求めた各成分は全て，未脱脂試料を基準 として算出した。

\section{4 酵素糖化}

アンモニア処理した試料について酵素糖化を行った。アン モニア処理試料 $500 \mathrm{mg}$ に, 水 $7235 \mu \mathrm{L}, 150 \mathrm{mM}$ 酢酸ナ卜 リウム緩衝液（pH 5.0） $1500 \mu \mathrm{L}$ ，抗生物質 (10 mg/mL シ クロヘキシド : $10 \mathrm{mg} / \mathrm{mL}$ テトラサイクリン = 6:8） $140 \mu \mathrm{L}$, 酵素剂 Accellerase DUET（ジェネンコア協和） $625 \mu \mathrm{L}$ を加 え， $50^{\circ} \mathrm{C} ， 200 \mathrm{rpm}$ で 24 時間振とうして酵素糖化を行った。 得られた酵素糖化液を遠心分離して上澄みを回収し，水で 適当な濃度に希釈した。バイオセンサーBF-7（王子計測機 器株式会社) を用いてこの希釈液のグルコース濃度を測定し, アンモニア処理試料 $500 \mathrm{mg}$ の酵素糖化により得られたグル コース収量 $X_{1}(\mathrm{mg})$ を算出した。さらに, アンモニア処理 試料単位乾燥重量当たりの硫酸加水分解により生成するグ ルコース量を $\mathrm{X}_{2}(\mathrm{~g} / \mathrm{kg}$ dry biomass $(\mathrm{BM}))$ として, C6 糖 化率 $\mathrm{Y}(\%)$ を以下のように定義した。

$$
\mathrm{Y}(\%)=\mathrm{X}_{1}(\mathrm{mg}) \div\left(\mathrm{X}_{2}(\mathrm{~g} / \mathrm{kg}) \times 500(\mathrm{mg})\right.
$$

$$
\div 1000(\mathrm{~g} / \mathrm{kg})) \times 100
$$

ここで，アンモニア前処理前後で糖類の損失がほとんどな いため, アンモニア前処理前後でのグルコース含有率は変化 しないとした。

\section{5 重回帰分析}

C6 糖化率に影響を与える成分を調べるため, 重回帰分析 を行った。各アンモニア処理条件について，C6 糖化率を目 的変数, 各成分の定量值を説明变数にして重回帰分析を行っ た。取り込む説明変数を最大 4 とし, 総当たり法により AIC （赤池情報量）が最小となる式を求めた。各成分と栽培条件 は相互に独立であるとは限らないため，多重共線性は除去し た。

\section{3. 結果と考察}

\section{1 同一圃場での栽培期間と糖化性}

エタノールの生産量は，原料中の成分組成に強く影響され るため, 原料植物の栽培条件と原料の品質管理が重要であ り，そのためには何らかの指標が必要である。我々が原料と して用いているネピアグラスはインドネシアでは年間を通じて 収穫できるので，栽培期間を指標として用いることを検討し た。

なお，C5 糖を利用できる酵母の開発も行われているが, 原料を選ぶ観点からは，利用が容易な C6 糖を多く得られる ものの方が価值が高いと考え，本論文においては，主にC6 糖に着目して検討を行った。

まず，同じ K1 固場で栽培された栽培期間が異なるネピア グラス（Table 1 No. 1～5）について, 同じ条件でアンモニ ア処理を施し酵素糖化を行った。酵素糖化で得られた C6 糖化率と栽培期間を比較したところ，負の相関があり，栽培 期間が長くなると C6 糖化率が減少していた (Fig. 2)。この ように栽培期間と C6 糖化率に負の相関が見られたのは，生 長するに従って，七ルロースやへミセルロース，リグニンの含 有率の増加やタンパク質の減少など，成分組成が変化するこ とと関係していると考えられた。国内の同一國場（東京大学 大学院農学生命科学研究科附属生態調和農学機構）におけ る栽培期間と成分変化・酵素糖化性については, 古久保ら 9) が詳細に検討を行っている。

\section{2 様々な圃場での栽培期間と成分の比較}

バイオエタノールを製造する際には，大量のバイオマスを 必要とすることから，生産戋場や栽培時期が多岐にわたる と予想され，栽培期間以外にも様々な条件のもとで栽培され たネピアグラスが原料となる。このため，栽培条件が異なる

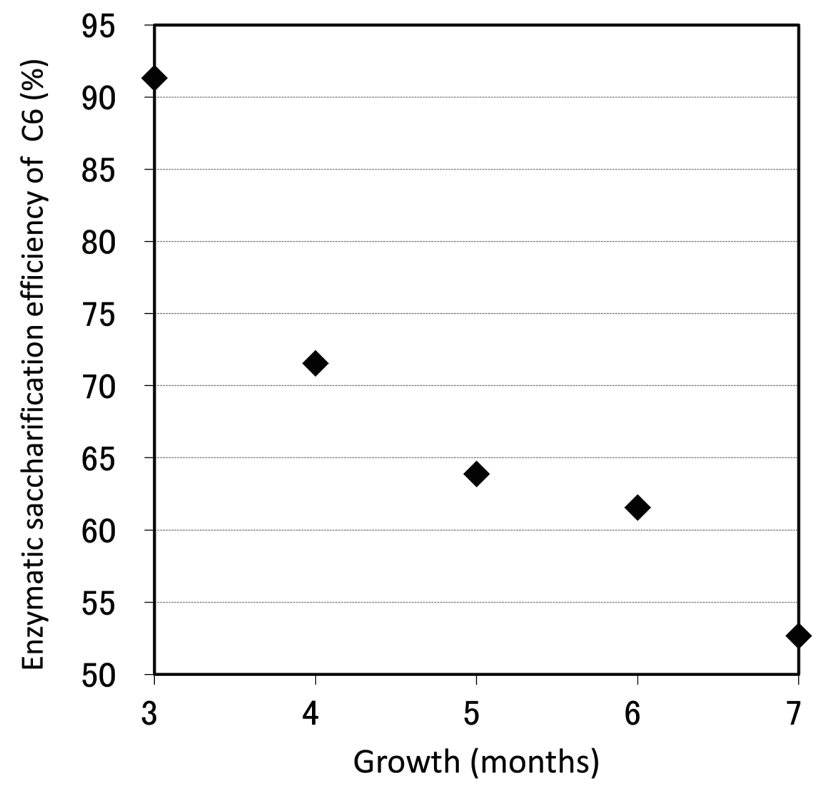

Fig. 2 Relationship between growth and enzymatic saccharification efficiency of C6 at single location (K1) 
围場から収穫してきたネピアグラスについても，成分変化や C6 糖化率を調べる必要がある。そこで, 雨季・乾季や施肥 条件, 土壤の状態などが異なる戋場から収穫してきたネピア グラスについても, 同様にアンモニア処理を施して醳素糖化 を行い，栽培期間に対して C6 糖化率や成分の変化を調心 た。栽培期間と C6 糖化率の比較を Fig. 3 に, 栽培期間と 主な成分 (Glc, Xyl，TGAL，CP) を比較した結果を Fig. 4 〜 7示した。(上記以外の成分も併せて, 栽培期間と各成 分の単相関係数を Table 2 に示した。）な㧍，雨季・乾季や 施肥条件, 土壤の状態など栽培期間以外の栽培条件に対し ても，C6 糖化率や各成分を比較したが，相関は見られなかっ た。

C6 糖化率と栽培期間を比較したところ, 同一围場の場合 と同様に, 栽培期間が長くなると C6 糖化率が減少する傾 向ではあったが, 同じ栽培期間でも，例えば5 ケ月では C6

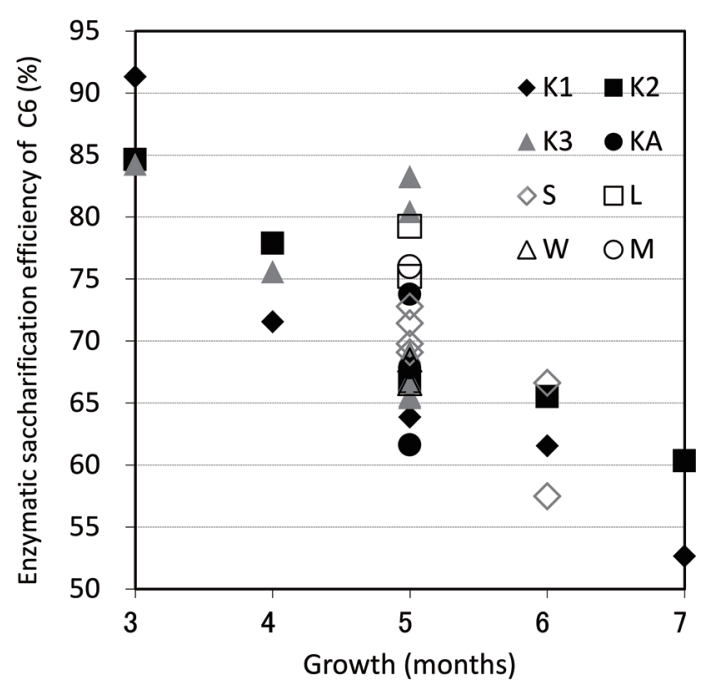

Fig. 3 Relationship between growth and enzymatic saccharification efficiency of $\mathrm{C} 6$ at multiple locations

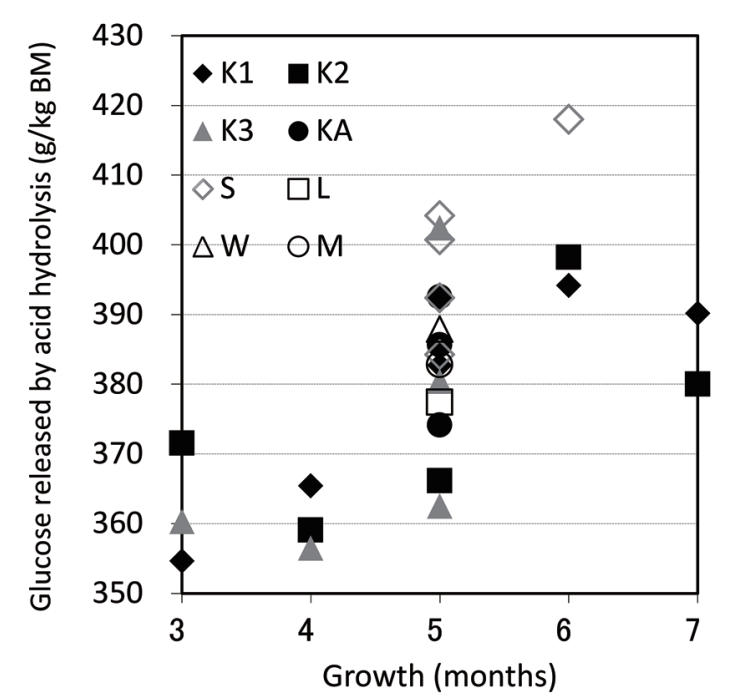

Fig. 4 Relationship between growth and Glc in Napiergrass at multiple locations

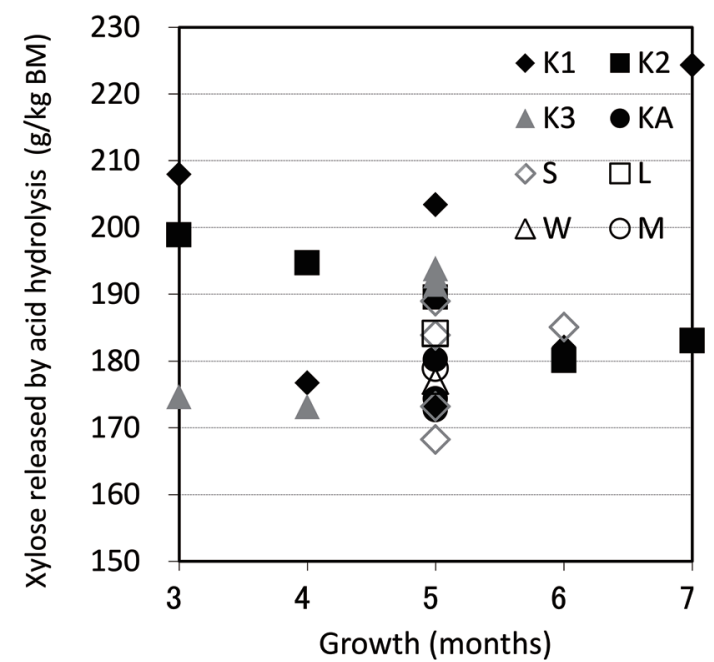

Fig. 5 Relationship between growth and Xyl in Napiergrass at multiple locations

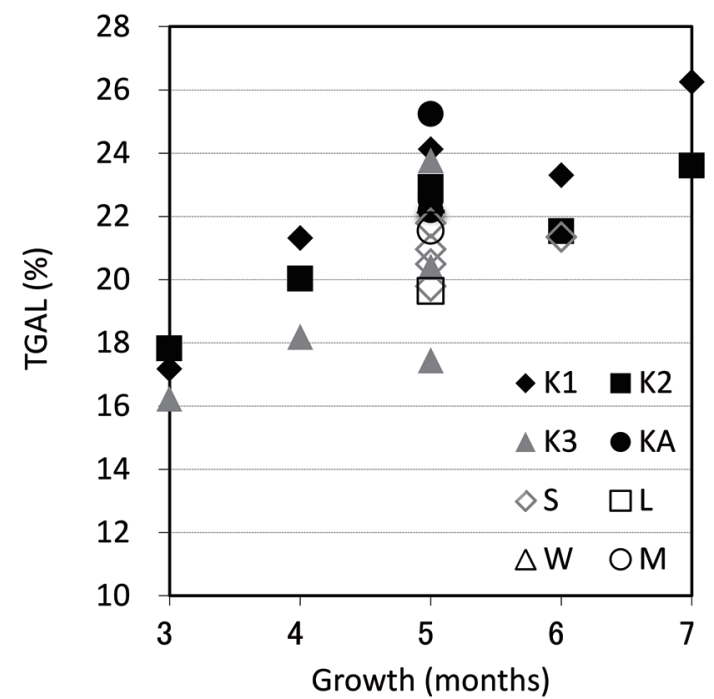

Fig. 6 Relationship between growth and lignin content (TGAL) in Napiergrass at multiple locations

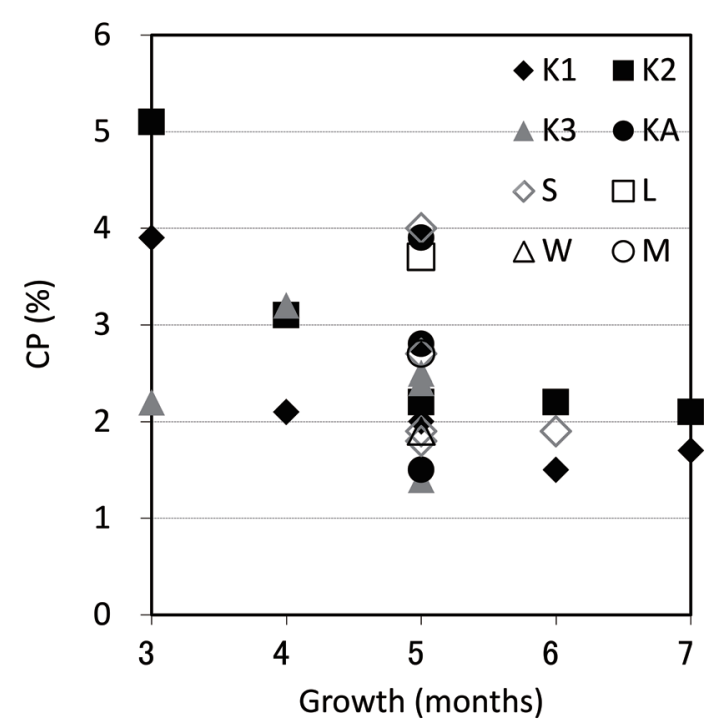

Fig. 7 Relationship between growth and CP in Napiergrass at multiple locations 
Table 2 Correlation coefficients between growth and each component in Napiergrass

\begin{tabular}{|c|c|}
\hline Components & Correlation coefficient with growth \\
\hline Ash content & $-0.36^{*}$ \\
\hline Alcohol-benzene extractives & -0.15 \\
\hline Klason lignin & $0.70^{* *}$ \\
\hline Holocellulose & 0.20 \\
\hline$\alpha$-Cellulose & $0.53^{* *}$ \\
\hline Hemicellulose & $-0.56^{* *}$ \\
\hline TGAL & $0.66^{* *}$ \\
\hline $\mathrm{CP}$ & $-0.49^{* *}$ \\
\hline $\mathrm{BP}$ & -0.32 \\
\hline NDICP & -0.33 \\
\hline NDF & $0.39 *$ \\
\hline $\mathrm{ADF}$ & $0.52^{* *}$ \\
\hline $\mathrm{ADL}$ & 0.29 \\
\hline $\mathrm{NFC}$ & -0.09 \\
\hline $\mathrm{EE}$ & -0.15 \\
\hline Crude ash & $-0.42^{*}$ \\
\hline $\mathrm{Ca}$ & 0.14 \\
\hline $\mathrm{P}$ & -0.26 \\
\hline $\mathrm{Mg}$ & $-0.52^{* *}$ \\
\hline $\mathrm{K}$ & -0.04 \\
\hline $\mathrm{K} /(\mathrm{Ca}+\mathrm{Mg})$ & 0.09 \\
\hline OCC & -0.15 \\
\hline OCW & 0.27 \\
\hline $\mathrm{Oa}$ & $-0.58^{* *}$ \\
\hline $\mathrm{Ob}$ & $0.58^{* *}$ \\
\hline Acetyl group & $0.40^{*}$ \\
\hline Glc & $0.60^{* *}$ \\
\hline Xyl & 0.07 \\
\hline
\end{tabular}

糖化率が 61.6 ～83.3\%と大きくばらついていた。また，成 分と栽培期間の比較でも, Glcでは $363 \sim 404 \mathrm{~g} / \mathrm{kg} \mathrm{BM}$, TGAL では $17.4 〜 25.2 \%$ とばらつきが大きく, 栽培期間より も栽培条件が成分組成, 糖化率に与える影響が大きいと考 えられた。Fig. 2 のように, 同じ圃場では C6 糖化率と栽培 期間に相関が見られたことから，ネピアグラスの生長と成分 の変化に何らかの関係はあると推察されるが, 様々な戋場か ら原料を集めてくる場合は，栽培期間だけを指標として原料 を管理することは難しいことが分かった。そこで，原料管理 に最適な指標を得るため, 成分と C6 糖化率の相関を調べる ことにした。

\section{3 原料の成分と糖化率の比較}

原料管理に最適な指標を得るため，原料の各成分と C6 糖化率の単相関係数を求めた。結果を Table 3 に示す。本 研究で採用したアンモニアによる前処理に対して, 原料成分 と糖化率の相関に関する知見がほとんど無いため, 草本に適 した飼料分析以外に木材の化学成分分析やキシランのアセ チル基分析，イネに適したTGAL なども併せて実施した。各 試料の成分分析の結果と C6 糖化率を Tables 4-1 4-4に 示す。その中でも C6 糖化率とやや強い相関 $(|\mathrm{r}|>0.7)$ があっ た成分は, 相関の良い順に, TGAL, Ob であった (Figs. 8, 9)。
一般にリグニンはセルロースへの酵素の接近を妨げ酵素糖 化を阻害すると考えられている10)。今回のようなアンモニアに よる前処理を施した試料についても，TGALと C6 糖化率に やや強い負の相関が見られ，既往の知見と一致した。また， ネピアグラスは成長が進むにつれてリグニン含量が増加する ことが知られており 11) 12)，栽培期間との間に負の相関がみら れたことと一致する（Fig. 6, Table 2)。Obは, 酵素によっ て分解しない成分なので，C6 糖化率と負の相関が見られた ことは妥当と考えられた。

単相関係数の結果から, 原料管理の指標にはC6 糖化 率と最も相関が強かったTGAL が適していると考えられた。 Fig. 8 より TGAL と C6 糖化率の近次式が得られたことから, 原料の TGALを調べるだけで, C6 糖化率をある程度まで 予測できる。ただし, 今回の実験に用いた酵素剤 DUET は, セルラーゼだけでなくキシラナーゼ等も含む複合酵素である ように，単一の成分が糖化率に影響を与えているのではな く，複数の成分が糖化率に影響を与えていると考えられたた め, 重回帰分析を行った。C6 糖化率を目的変数, 各成分を 説明変数とし, 取り込む説明変数を最大 4 , 総当たり法によ り AIC が最小となる式を求めた。アンモニア処理試料の C6 糖化率 (目的変数) に対して, AIC が最小となった組合せ の説明変数や標準偏回帰係数, P- 值の結果を Table 5, 得 
Table 3 Correlation coefficient between enzymatic saccharification efficiency of C6 and each component in Napiergrass

\begin{tabular}{|c|c|}
\hline Components & Correlation coefficient with enzymatic saccharification efficiency of C6 \\
\hline Ash content & $0.64^{* *}$ \\
\hline Alcohol-benzene extractives & 0.05 \\
\hline Klason lignin & $-0.61^{* *}$ \\
\hline Holocellulose & -0.32 \\
\hline$\alpha$-Cellulose & $-0.64^{* *}$ \\
\hline Hemicellulose & $0.57^{* *}$ \\
\hline TGAL & $-0.81^{* *}$ \\
\hline$\overline{\mathrm{CP}}$ & $0.65^{* *}$ \\
\hline BP & $0.55^{* *}$ \\
\hline NDICP & $0.50^{* *}$ \\
\hline $\mathrm{NDF}$ & $-0.49^{* *}$ \\
\hline $\mathrm{ADF}$ & $-0.59^{* *}$ \\
\hline $\mathrm{ADL}$ & $-0.35^{*}$ \\
\hline NFC & 0.04 \\
\hline$\overline{\mathrm{EE}}$ & 0.07 \\
\hline Crude ash & $0.67^{* *}$ \\
\hline $\mathrm{Ca}$ & -0.04 \\
\hline $\mathrm{P}$ & $0.35^{*}$ \\
\hline $\mathrm{Mg}$ & $0.43^{*}$ \\
\hline $\mathrm{K}$ & $0.35^{*}$ \\
\hline $\mathrm{K} /(\mathrm{Ca}+\mathrm{Mg})$ & 0.17 \\
\hline$\overline{\mathrm{OCC}}$ & 0.23 \\
\hline$\overline{\mathrm{OCW}}$ & $-0.42^{*}$ \\
\hline $\mathrm{Oa}$ & $0.58^{* *}$ \\
\hline $\mathrm{Ob}$ & $-0.71^{* *}$ \\
\hline Acetyl group & -0.32 \\
\hline Glc & $-0.66^{* *}$ \\
\hline$\underline{\mathrm{Xyl}}$ & -0.01 \\
\hline
\end{tabular}

Table 4-1 Enzymatic saccharification efficiency of C6 and each component in Napiergrass samples

\begin{tabular}{|c|c|c|c|c|c|}
\hline No. & $\begin{array}{c}\text { Enzymatic saccharification } \\
\text { efficiency of } \mathrm{C} 6\end{array}$ & Ash content & $\begin{array}{c}\text { Alcohol-benzene } \\
\text { extractives }\end{array}$ & Klason lignin & Holocellulose \\
\hline 1 & 91.3 & 8.2 & 7.6 & 16.3 & 63.1 \\
\hline 2 & 71.5 & 6.3 & 9.6 & 19.6 & 63.6 \\
\hline 3 & 63.9 & 6.4 & 9.5 & 20.1 & 61.3 \\
\hline 4 & 61.6 & 4.4 & 10.6 & 20.7 & 62.9 \\
\hline 5 & 52.7 & 5.3 & 8.4 & 23.9 & 62.8 \\
\hline 6 & 84.6 & 9.3 & 6.0 & 17.5 & 63.8 \\
\hline 7 & 77.9 & 8.5 & 7.2 & 19.0 & 65.0 \\
\hline 8 & 66.7 & 6.6 & 8.0 & 21.1 & 62.3 \\
\hline 9 & 65.5 & 6.6 & 9.6 & 20.8 & 62.1 \\
\hline 10 & 60.3 & 5.9 & 8.9 & 21.0 & 63.5 \\
\hline 11 & 84.3 & 7.1 & 15.8 & 14.9 & 58.8 \\
\hline 12 & 75.6 & 6.7 & 14.2 & 17.7 & 59.9 \\
\hline 13 & 65.4 & 6.5 & 10.8 & 18.3 & 62.8 \\
\hline 14 & 68.4 & 6.5 & 10.8 & 18.3 & 62.8 \\
\hline 15 & 65.6 & 6.5 & 10.8 & 18.3 & 62.8 \\
\hline 16 & 80.4 & 9.7 & 12.5 & 21.0 & 58.4 \\
\hline 17 & 83.3 & 9.7 & 12.5 & 21.0 & 58.4 \\
\hline 18 & 69.1 & 7.4 & 5.4 & 19.9 & 64.2 \\
\hline 19 & 66.9 & 7.4 & 5.4 & 19.9 & 64.2 \\
\hline 20 & 67.8 & 3.9 & 5.4 & 24.5 & 64.8 \\
\hline 21 & 73.8 & 5.1 & 9.7 & 21.6 & 62.5 \\
\hline 22 & 61.6 & 4.1 & 14.7 & 20.9 & 61.2 \\
\hline 23 & 61.6 & 4.1 & 14.7 & 20.9 & 61.2 \\
\hline 24 & 71.4 & 8.7 & 3.7 & 21.2 & 66.1 \\
\hline 25 & 69.1 & 10.3 & 4.4 & 20.5 & 64.2 \\
\hline 26 & 69.8 & 5.6 & 8.5 & 19.2 & 63.9 \\
\hline 27 & 72.8 & 5.8 & 13.3 & 18.5 & 61.3 \\
\hline 28 & 57.5 & 6.1 & 5.8 & 21.3 & 66.6 \\
\hline 29 & 66.6 & 6.1 & 5.8 & 21.3 & 66.6 \\
\hline 30 & 75.2 & 8.3 & 9.3 & 18.4 & 59.5 \\
\hline 31 & 79.2 & 8.3 & 9.3 & 18.4 & 59.5 \\
\hline 32 & 66.6 & 5.5 & 11.6 & 21.5 & 62.0 \\
\hline 33 & 68.5 & 5.5 & 11.6 & 21.5 & 62.0 \\
\hline 34 & 76.0 & 8.4 & 3.7 & 20.1 & 66.1 \\
\hline
\end{tabular}


Table 4-2 Enzymatic saccharification efficiency of $\mathrm{C} 6$ and each component in Napiergrass samples

\begin{tabular}{|c|c|c|c|c|c|c|c|c|c|}
\hline No. & $\alpha$-Cellulose & Hemicellulose & TGAL & $\mathrm{CP}$ & $\mathrm{BP}$ & NDICP & $\mathrm{NDF}$ & $\mathrm{ADF}$ & ADL \\
\hline 1 & 34.8 & 28.3 & 17.2 & 3.9 & 2.0 & 2.2 & 76.7 & 49.6 & 10.4 \\
\hline 2 & 37.6 & 26.0 & 21.3 & 2.1 & 1.3 & 1.3 & 79.5 & 56.5 & 18.7 \\
\hline 3 & 37.0 & 24.3 & 24.1 & 2.0 & 1.3 & 1.5 & 77.9 & 55.7 & 14.6 \\
\hline 4 & 38.8 & 24.2 & 23.3 & 1.5 & 1.0 & 1.4 & 83.0 & 59.9 & 17.4 \\
\hline 5 & 39.3 & 23.6 & 26.2 & 1.7 & 1.1 & 1.5 & 81.3 & 60.5 & 15.7 \\
\hline 6 & 34.5 & 29.3 & 17.8 & 5.1 & 1.9 & 2.9 & 78.7 & 51.2 & 9.9 \\
\hline 7 & 37.2 & 27.7 & 20.0 & 3.1 & 1.5 & 2.1 & 81.5 & 55.9 & 13.7 \\
\hline 8 & 35.9 & 26.4 & 22.9 & 2.2 & 1.4 & 1.6 & 79.2 & 55.1 & 13.8 \\
\hline 9 & 37.6 & 24.5 & 21.5 & 2.2 & 1.6 & 1.7 & 77.9 & 55.7 & 17.7 \\
\hline 10 & 38.4 & 25.1 & 23.6 & 2.1 & 1.5 & 1.8 & 79.3 & 57.4 & 15.2 \\
\hline 11 & 33.4 & 25.4 & 16.2 & 2.2 & 1.3 & 1.4 & 71.2 & 46.1 & 6.9 \\
\hline 12 & 33.5 & 26.4 & 18.2 & 3.2 & 1.7 & 2.3 & 74.3 & 49.0 & 10.1 \\
\hline 13 & 37.3 & 25.5 & 20.4 & 1.4 & 1.2 & 1.0 & 77.9 & 50.5 & 9.9 \\
\hline 14 & 37.3 & 25.5 & 20.4 & 1.4 & 1.2 & 1.0 & 77.9 & 50.5 & 9.9 \\
\hline 15 & 37.3 & 25.5 & 20.4 & 1.4 & 1.2 & 1.0 & 77.9 & 50.5 & 9.9 \\
\hline 16 & 32.3 & 26.1 & 17.4 & 2.4 & 1.6 & 1.8 & 76.2 & 49.1 & 8.6 \\
\hline 17 & 32.3 & 26.1 & 17.4 & 2.4 & 1.6 & 1.8 & 76.2 & 49.1 & 8.6 \\
\hline 18 & 37.1 & 27.1 & 23.8 & 2.5 & 1.5 & 1.5 & 78.8 & 56.3 & 10.7 \\
\hline 19 & 37.1 & 27.1 & 23.8 & 2.5 & 1.5 & 1.5 & 78.8 & 56.3 & 10.7 \\
\hline 20 & 39.0 & 25.8 & 25.2 & 2.8 & 1.9 & 2.4 & 86.3 & 66.6 & 24.1 \\
\hline 21 & 37.4 & 25.0 & 22.2 & 3.9 & 2.3 & 2.3 & 82.0 & 61.1 & 22.9 \\
\hline 22 & 37.8 & 23.4 & 22.5 & 1.5 & 1.1 & 1.4 & 78.8 & 57.2 & 13.8 \\
\hline 23 & 37.8 & 23.4 & 22.5 & 1.5 & 1.1 & 1.4 & 78.8 & 57.2 & 13.8 \\
\hline 24 & 41.3 & 24.8 & 21.8 & 2.7 & 1.5 & 2.0 & 83.5 & 63.0 & 26.9 \\
\hline 25 & 39.6 & 24.6 & 20.5 & 4.0 & 1.8 & 2.0 & 80.0 & 58.2 & 18.9 \\
\hline 26 & 40.8 & 23.1 & 21.0 & 1.9 & 0.9 & 1.3 & 81.0 & 59.6 & 12.9 \\
\hline 27 & 38.8 & 22.5 & 19.8 & 1.8 & 0.9 & 1.5 & 76.5 & 57.2 & 12.0 \\
\hline 28 & 41.6 & 25.0 & 21.3 & 1.9 & 1.2 & 1.6 & 82.6 & 62.4 & 13.3 \\
\hline 29 & 41.6 & 25.0 & 21.3 & 1.9 & 1.2 & 1.6 & 82.6 & 62.4 & 13.3 \\
\hline 30 & 34.8 & 24.7 & 19.6 & 3.7 & 1.8 & 1.8 & 73.4 & 51.4 & 10.4 \\
\hline 31 & 34.8 & 24.7 & 19.6 & 3.7 & 1.8 & 1.8 & 73.4 & 51.4 & 10.4 \\
\hline 32 & 37.3 & 24.8 & 22.5 & 1.9 & 1.1 & 1.6 & 82.2 & 60.0 & 13.2 \\
\hline 33 & 37.3 & 24.8 & 22.5 & 1.9 & 1.1 & 1.6 & 82.2 & 60.0 & 13.2 \\
\hline 34 & 39.6 & 26.5 & 21.5 & 2.7 & 1.6 & 2.0 & 80.6 & 57.4 & 10.7 \\
\hline
\end{tabular}

Table 4-3 Enzymatic saccharification efficiency of C6 and each component in Napiergrass samples

\begin{tabular}{|c|c|c|c|c|c|c|c|c|}
\hline No. & NFC & $\mathrm{EE}$ & Crude ash & $\mathrm{Ca}$ & $\mathrm{P}$ & $\mathrm{Mg}$ & $\mathrm{K}$ & $\mathrm{K} /(\mathrm{Ca}+\mathrm{Mg})$ \\
\hline 1 & 12.0 & 1.0 & 8.6 & 0.2 & 0.1 & 0.4 & 0.8 & 0.4 \\
\hline 2 & 11.9 & 1.2 & 6.6 & 0.2 & 0.0 & 0.3 & 0.4 & 0.3 \\
\hline 3 & 15.1 & 0.7 & 5.8 & 0.2 & 0.0 & 0.2 & 0.7 & 0.7 \\
\hline 4 & 11.6 & 0.9 & 4.4 & 0.1 & 0.0 & 0.2 & 0.5 & 0.6 \\
\hline 5 & 13.2 & 0.7 & 4.6 & 0.2 & 0.0 & 0.2 & 0.4 & 0.5 \\
\hline 6 & 9.5 & 0.7 & 8.9 & 0.0 & 0.1 & 0.3 & 1.2 & 1.1 \\
\hline 7 & 9.2 & 0.7 & 7.6 & 0.3 & 0.1 & 0.3 & 0.7 & 0.5 \\
\hline 8 & 12.3 & 1.0 & 6.9 & 0.2 & 0.0 & 0.2 & 0.8 & 0.8 \\
\hline 9 & 14.4 & 0.8 & 6.4 & 0.2 & 0.0 & 0.2 & 0.7 & 0.8 \\
\hline 10 & 13.4 & 0.8 & 6.2 & 0.2 & 0.0 & 0.2 & 0.4 & 0.4 \\
\hline 11 & 19.0 & 1.3 & 7.7 & 0.1 & 0.1 & 0.3 & 0.6 & 0.5 \\
\hline 12 & 16.7 & 1.2 & 6.9 & 0.1 & 0.1 & 0.2 & 0.7 & 0.9 \\
\hline 13 & 14.2 & 0.9 & 6.6 & 0.3 & 0.0 & 0.2 & 0.9 & 0.7 \\
\hline 14 & 14.2 & 0.9 & 6.6 & 0.3 & 0.0 & 0.2 & 0.9 & 0.7 \\
\hline 15 & 14.2 & 0.9 & 6.6 & 0.3 & 0.0 & 0.2 & 0.9 & 0.7 \\
\hline 16 & 13.3 & 1.1 & 8.8 & 0.3 & 0.0 & 0.2 & 1.3 & 1.0 \\
\hline 17 & 13.3 & 1.1 & 8.8 & 0.3 & 0.0 & 0.2 & 1.3 & 1.0 \\
\hline 18 & 12.0 & 0.8 & 7.4 & 0.3 & 0.1 & 0.3 & 0.8 & 0.6 \\
\hline 19 & 12.0 & 0.8 & 7.4 & 0.3 & 0.1 & 0.3 & 0.8 & 0.6 \\
\hline 20 & 8.7 & 0.7 & 3.9 & 0.2 & 0.0 & 0.2 & 0.3 & 0.3 \\
\hline 21 & 10.4 & 1.0 & 5.0 & 0.2 & 0.1 & 0.2 & 0.4 & 0.4 \\
\hline 22 & 14.8 & 1.0 & 5.3 & 0.1 & 0.0 & 0.1 & 0.3 & 0.4 \\
\hline 23 & 14.8 & 1.0 & 5.3 & 0.1 & 0.0 & 0.1 & 0.3 & 0.4 \\
\hline 24 & 6.7 & 0.8 & 8.3 & 0.2 & 0.1 & 0.2 & 1.4 & 1.5 \\
\hline 25 & 6.9 & 1.0 & 10.1 & 0.3 & 0.2 & 0.2 & 1.8 & 1.6 \\
\hline 26 & 11.6 & 0.8 & 6.0 & 0.0 & 0.1 & 0.1 & 1.0 & 3.5 \\
\hline 27 & 16.0 & 1.1 & 6.1 & 0.0 & 0.1 & 0.1 & 1.0 & 2.5 \\
\hline 28 & 9.8 & 1.2 & 6.1 & 0.2 & 0.2 & 0.1 & 1.3 & 2.1 \\
\hline 29 & 9.8 & 1.2 & 6.1 & 0.2 & 0.2 & 0.1 & 1.3 & 2.1 \\
\hline 30 & 14.5 & 0.7 & 9.5 & 0.2 & 0.0 & 0.1 & 2.5 & 4.6 \\
\hline 31 & 14.5 & 0.7 & 9.5 & 0.2 & 0.0 & 0.1 & 2.5 & 4.6 \\
\hline 32 & 10.7 & 1.6 & 5.2 & 0.2 & 0.0 & 0.1 & 0.9 & 1.3 \\
\hline 33 & 10.7 & 1.6 & 5.2 & 0.2 & 0.0 & 0.1 & 0.9 & 1.3 \\
\hline 34 & 9.3 & 1.0 & 8.4 & 0.1 & 0.2 & 0.1 & 1.1 & 2.6 \\
\hline
\end{tabular}


Table 4-4 Enzymatic saccharification efficiency of C6 and each component in Napiergrass samples

\begin{tabular}{|c|c|c|c|c|c|c|c|}
\hline No. & $\mathrm{OCC}$ & $\overline{\mathrm{OCW}}$ & $\mathrm{Oa}$ & $\mathrm{Ob}$ & Acetyl group & Glc & Xyl \\
\hline 1 & 14.8 & 76.6 & 15.1 & 61.6 & 2.1 & 354.6 & 208.0 \\
\hline 2 & 13.6 & 79.8 & 8.9 & 70.9 & 2.3 & 365.4 & 176.7 \\
\hline 3 & 19.4 & 74.8 & 0.4 & 74.4 & 2.1 & 382.7 & 203.4 \\
\hline 4 & 16.5 & 79.1 & 3.7 & 75.4 & 2.5 & 394.2 & 182.0 \\
\hline 5 & 15.1 & 80.4 & 0.5 & 79.9 & 2.2 & 390.2 & 224.3 \\
\hline 6 & 15.3 & 75.8 & 11.6 & 64.1 & 1.5 & 371.5 & 198.9 \\
\hline 7 & 12.1 & 80.3 & 6.9 & 73.4 & 2.0 & 359.0 & 194.7 \\
\hline 8 & 16.8 & 76.3 & 3.3 & 73.0 & 1.9 & 366.2 & 189.5 \\
\hline 9 & 16.7 & 76.9 & 2.5 & 74.4 & 2.1 & 398.2 & 180.1 \\
\hline 10 & 17.6 & 76.2 & 0.2 & 76.1 & 2.3 & 380.0 & 183.0 \\
\hline 11 & 22.8 & 69.6 & 6.0 & 63.6 & 1.9 & 360.3 & 174.7 \\
\hline 12 & 20.3 & 72.8 & 4.7 & 68.1 & 1.9 & 356.5 & 173.2 \\
\hline 13 & 22.4 & 71.0 & 3.4 & 67.6 & 2.1 & 402.4 & 191.5 \\
\hline 14 & 22.4 & 71.0 & 3.4 & 67.6 & 2.1 & 402.4 & 191.5 \\
\hline 15 & 22.4 & 71.0 & 3.4 & 67.6 & 2.1 & 402.4 & 191.5 \\
\hline 16 & 21.4 & 69.7 & 6.3 & 63.5 & 2.3 & 362.5 & 192.7 \\
\hline 17 & 21.4 & 69.7 & 6.3 & 63.5 & 2.3 & 362.5 & 192.7 \\
\hline 18 & 18.1 & 74.5 & 2.5 & 72.0 & 2.1 & 380.4 & 193.8 \\
\hline 19 & 18.1 & 74.5 & 2.5 & 72.0 & 2.1 & 380.4 & 193.8 \\
\hline 20 & 11.5 & 84.6 & 1.9 & 82.7 & 2.1 & 392.5 & 180.2 \\
\hline 21 & 15.0 & 80.0 & 0.3 & 79.7 & 2.2 & 374.1 & 172.7 \\
\hline 22 & 16.0 & 78.8 & 2.8 & 76.0 & 2.3 & 385.6 & 174.4 \\
\hline 23 & 16.0 & 78.8 & 2.8 & 76.0 & 2.3 & 385.6 & 174.4 \\
\hline 24 & 10.0 & 81.8 & 4.9 & 76.9 & 1.5 & 400.7 & 188.9 \\
\hline 25 & 15.4 & 74.5 & 1.0 & 73.6 & 1.2 & 392.4 & 183.8 \\
\hline 26 & 15.6 & 78.4 & 1.1 & 77.3 & 2.0 & 404.2 & 173.2 \\
\hline 27 & 18.4 & 75.6 & 4.5 & 71.1 & 2.0 & 384.2 & 168.3 \\
\hline 28 & 9.4 & 84.6 & 8.5 & 76.1 & 2.3 & 418.0 & 185.0 \\
\hline 29 & 9.4 & 84.6 & 8.5 & 76.1 & 2.3 & 418.0 & 185.0 \\
\hline 30 & 21.8 & 68.7 & 3.3 & 65.4 & 2.0 & 377.4 & 184.1 \\
\hline 31 & 21.8 & 68.7 & 3.3 & 65.4 & 2.0 & 377.4 & 184.1 \\
\hline 32 & 12.4 & 82.4 & 5.3 & 77.1 & 2.3 & 387.9 & 177.0 \\
\hline 33 & 12.4 & 82.4 & 5.3 & 77.1 & 2.3 & 387.9 & 177.0 \\
\hline 34 & 13.4 & 78.3 & $\begin{array}{l}0.2 \\
3.2\end{array}$ & 75.1 & 2.0 & 382.8 & 178.9 \\
\hline
\end{tabular}

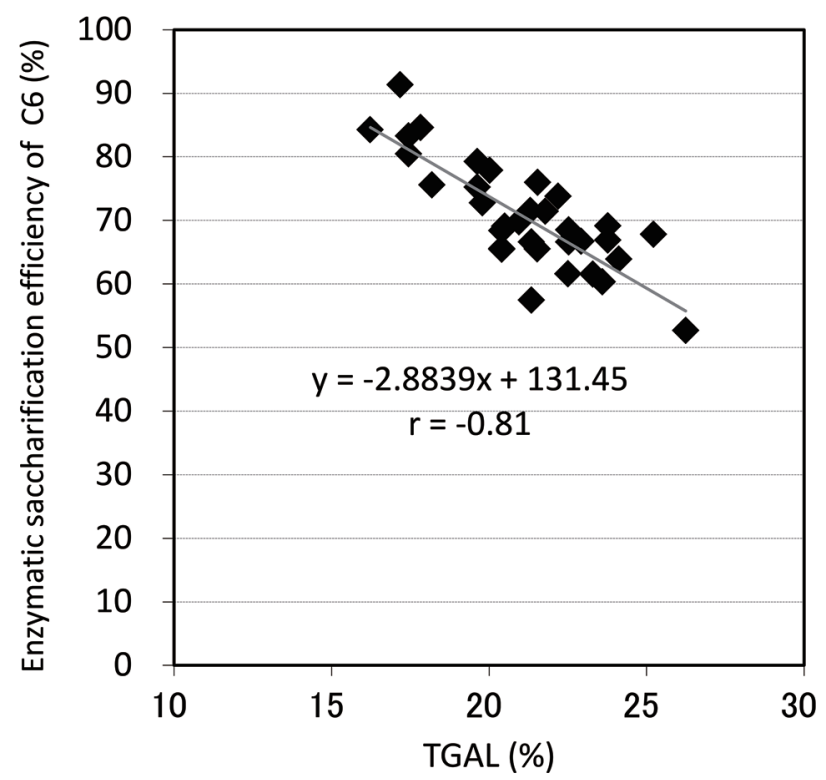

Fig. 8 Relationship between lignin content (TGAL) in Napiergrass and enzymatic saccharification efficiency of $\mathrm{C} 6$

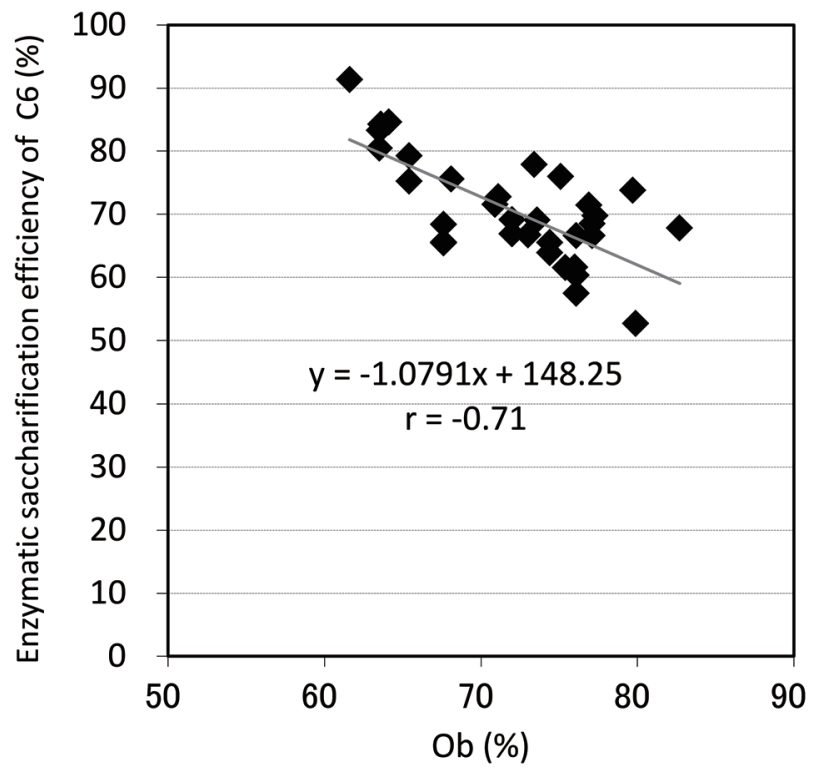

Fig. 9 Relationship between $\mathrm{Ob}$ in Napiergrass and enzymatic saccharification efficiency of $\mathrm{C} 6$ 
Table 5 Result of multiple regression analysis using enzymatic saccharification efficiency of C6 as a objective variable

\begin{tabular}{|c|c|c|c|}
\hline Explanatory variables & Coefficients & Standard partial regression coefficient & $p$-value \\
\hline Intercept & 159.88 & & $1.0 \mathrm{E}-10$ \\
\hline TGAL (\%) & -2.06 & -0.58 & $6.0 \mathrm{E}-08$ \\
\hline $\mathrm{Glc}(\mathrm{g} / \mathrm{kg} \mathrm{BM})$ & -0.14 & -0.27 & 0.003 \\
\hline $\mathrm{CP}(\%)$ & 2.76 & 0.30 & 0.001 \\
\hline AIC & & -57.68 & \\
\hline Multiple R & & 0.92 & \\
\hline R Square & & 0.85 & \\
\hline Adjusted R Square & & 0.83 & \\
\hline Standard Error & & 3.50 & \\
\hline Observations & & 34 & \\
\hline
\end{tabular}

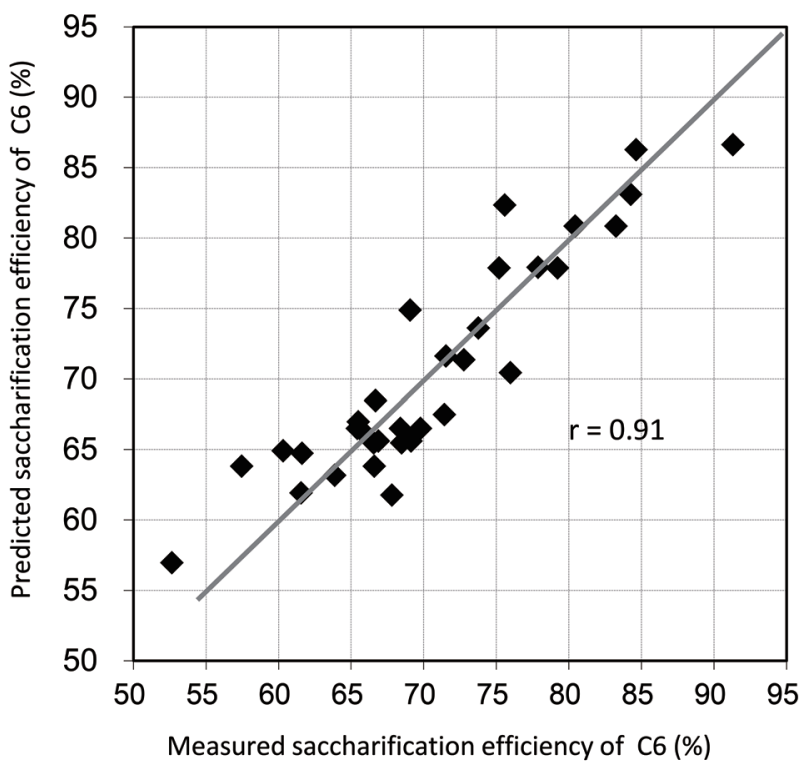

Fig. 10 Relationship between measured and predicted enzymatic saccharification efficiency of $\mathrm{C} 6$

られた予測式を式 (1)に示す。

$$
\mathrm{Y}=-2.06 \mathrm{X}_{1}-0.14 \mathrm{X}_{2}+2.76 \mathrm{X}_{3}+159.88
$$

(C6 糖化率を $\mathrm{Y}(\%), \mathrm{TGAL}$ を $\mathrm{X}_{1}(\%), \mathrm{Glc}$ を $\mathrm{X}_{2}(\mathrm{~g} / \mathrm{kg}$ $\mathrm{BM}), \mathrm{CP}$ を $\mathrm{X}_{3}(\%)$ とする

式 (1) から求めた C6 糖化率の予測值と実測值の相関を Fig. 10 に示す。この予測式を用いると標準誤差 3.50 で, 原 料成分から C6 糖化率を予測できる。

また，式（1）は，C6 糖化率に対して TGAL と Glc は負の 相関，CP は正の相関があることを示している。単相関係数 の結果と同様に、リグニン量が増えるとセルロースへの酵素 の接近を妨げ酵素糖化を阻害するため，TGALは負の相関 になっていると考えられる。Glc や CP については，式 (1) によると Glc が少なく， CP が多い試料が高い C6 糖化率を 得られると示されている。栽培期間との比較で Glc は弱い負 の相関，CP は弱い正の相関が見られたことから (Figs. 4, 7, Table 2), Glc が少なくCP が多い試料は生育が進んでいな い若い組織と考えられ，同一圃場での栽培期間と糖化率の 比較では栽培期間が短い方が C6 糖化率が高かったことか ら (Fig. 2), 若い組織からは高い C6 糖化率が得られると推
察されるので, 式 (1) で Glc が負の相関，CP が正の相関と なったことは妥当と考えられた。ただし, 栽培期間が短いも のが若い組織とは限らないことが Figs. 4〜 7で示されてい る。TGALと Glc が少なく, CP が多い原料を用いれば，高 いC6 糖化率が得られると導き出されるので, このような成 分組成の原料を得られる栽培条件が分かれば, 原料管理に さらに役立つと期待できる。

\section{4. 結 論}

同じ圑場で栽培されたネピアグラスでは，栽培期間と C6 糖化率に負の相関が見られ，栽培期間が長くなるにつれ酵 素糖化性が下がった。これまで成分分析の結果は，栽培期 間が 2 ケ月までのものしかなかったが，栽培期間 3 ケかから 7 ケ月の間のネピアグラスの成分分析を行うことにより，長期 間の栽培により TGAL と Glc は増加する傾向が見られ，Xyl はあまり増加しない, また， CP は減少傾向になることが明 らかとなった。しかし，同じ栽培期間でも戒場が異なるとグ ルコース含量や TGAL に差が見られ，糖化率もばらつきが大 きいため, 栽培期間は原料管理の指標には適切ではないこ とが示された。

原料の各成分と C6 糖化率の単相関係数を調べたところ, 原料の TGAL とアンモニア処理後の C6 糖化率にやや強い 相関が見られたことから，原料管理の指標には TGAL が 適していると考えられた。加えて, 重回帰分析の結果から, TGAL，Glc，CP の 3 指標を用いれば，C6 糖化率をさらに 精度良く予測できると考えられ，これらを原料管理の指標と して用いれば，原料の TGAL， Glc，CP を調べるだけで酵 素糖化工程における糖化率が予測できるだけでなく, さらに は予測糖化率と Glc を使って糖収量も導き出せるため, バイ オエタノール製造全体の生産管理にも役立つと期待できる。

\section{謝 辞}

本研究は (独) 新エネルギー・産業技術研究開発機構 （NEDO）からの受託事業「セルロース系エ夕ノール革新的生 産システム開発事業」として実施したものである。本研究を 遂行するにあたり，材料の提供に尽力いただいた PTトヨ夕. バイオ・インドネシアの各氏，イネ科植物の分析法を指導い ただいた農業・食品産業技術総合研究機構作物研究所の近 
藤始彦氏，荒井裕見子氏，趙鋭氏ほか関係各位に感謝申し 上げる。

\section{文 献}

1) Yasutani, I.; Suzuki, T.; Matui, K.; Ogawa, H.; Morita, E.; Morita, S., Baiomasu Kagaku Kaigi Happyou Ronbunshu, 7, p. 118 (2012): 保谷泉, 鈴木剛, 松井邦夫, 小川浩司, 守田英太郎, 森田茂紀, 第 7 回バイオマス科 学会議論文集, p. 118 (2012)

2) Miyagi, E., Grassl. Sci., 29(3), 232-240 (1983) : 宮城悦生, 日本草地学会誌, 29(3), 232-240 (1983)

3) Niwa, M.; Iguchi, Y.; Isomura, Y.; Uemura, T.; Aoyagi, K.; Mihashi, S., Baiomasu Kagaku Kaigi Happyou Ronbunshu, 7, p. 120(2012): 丹羽雅裕, 井口靖敏, 磯村 佳功, 上村毅, 青柳健一, 三橋秀一, 第 7 回バイオマス科 学会議論文集, p. 120 (2012)

4) The Japan Wood Research Society Ed., Mokushitsu Kagaku Jikken Manual, Buneido-shuppan, (2000) : 日本 木材学会編, 木質科学実験マニュアル, 文永堂出版, (2000)

5) Suzuki, S.; Suzuki, Y.; Yamamoto, N.; Hattori, T.; Sakamoto, M.; Umezawa, T. Plant Biotechnol., 26, 337-340 (2009)

6) Jikyu Shiryou Riyou Kenkyukai Ed., Soshiryou no Hinshitu Guidebook, 3rd ed, Japan Grassland Agriculture and Forage Seed Association, (2009) : 自給
飼料利用研究会編, 粗飼料の品質評価ガイドブック, 三訂 版, 日本草地畜産種子協会, (2009)

7) Food and Agricultural Materials Inspection Center and Shiryou Bunseki Kijun Kenkyukai Ed., Shiryou Bunsekihou Kaisetsu I, Japan Scientific Feeds Association, (2009): 独立行政法人農林水産消費安全技 術センター・飼料分析基準研究会編, 飼料分析法·解説 I, 日本科学飼料協会, (2009)

8) Sluiter, A.; Hames, B.; Ruiz, R.; Scarlata, C.; Sluiter, J.; Templeton, D.; Crocker, D., Determination of structural carbohydrates and lignin in biomass, Laboratory analytical procedure, (2008)

9) Kokubo, M.; Kurosawa, M.; Yamashita, T.; Sakuragi, K.; Shiotsu, F.; Igarashi, K.; Morita, S.; Samejima, M., J. Jpn. Inst. Energy (submitted): 古久保美樹, 黒澤美幸, 山下達也, 櫻木潔, 塩津文隆, 五十嵐圭日子, 森田茂紀, 鮫島正浩, 日本エネルギー学会誌 (投稿中)

10) Chen, F.; Dixon, R. A., Nature biotechnology, 25(7), 759-761 (2007)

11) Tanaka, S.; Ito, K.; Miyagi, E.; Inanaga, S., Jpn, J. Crop Sci., 58(4), 562-568 (1989): 田中重行, 伊藤浩司, 宮城悦生, 稲永忍，日本作物學會紀事, 58(4), 562-568 (1989)

12) Tsuruta, S.; Akashi, R.; Kawamura, O.; Numaguchi, H., Grassl. Sci., 47(6), 604-609 (2002)：霍田真一，明石良，川 村修，沼口寞次，日本草地学会誌，47(6), 604-609 (2002) 